\title{
Challenges of the recreational use of Amazon beaches
}

Luci Cajueiro Carneiro Pereira ${ }^{\mathrm{a}, 1}$, Rosigleyse Corrêa de Sousa-Felix ${ }^{\mathrm{b}}$, Rauquírio Marinho da Costa ${ }^{c}$, José António Jimenez ${ }^{\mathrm{d}}$.

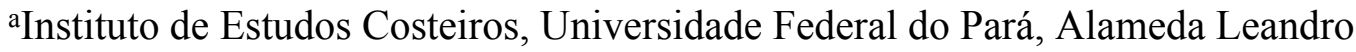
Ribeiro, s/n, Aldeia, 68600-000, Bragança, Pará, Brazil. Email: cajueiro@ufpa.br.

b Instituto de Estudos Costeiros, Universidade Federal do Pará, Alameda Leandro Ribeiro, s/n, Aldeia, 68600-000, Bragança, Pará, Brazil. E-mail: rosigleyse@yahoo.com.br mailto:rosigleyse@yahoo.com.br 'Instituto de Estudos Costeiros, Universidade Federal do Pará, Alameda Leandro Ribeiro, s/n, Aldeia, 68600-000, Bragança, Pará, Brazil. E-mail: raucosta@ufpa.br 'Laboratori d’Enginyeria Marítima, Universitat Politècnica de Catalunya· BarcelonaTech, c/Jordi Girona 1-3, Campus Nord ed D1, 08034 Barcelona, Spain. Email: jose.jimenez@upc.edu.

\footnotetext{
${ }^{1}$ Corresponding Author: L. C. C. Pereira. E-mail address: cajueiro@ufpa.br, luci.pereira@pq.cnpq.br Permanent address: Instituto de Estudos Costeiros, Universidade Federal do Pará, Alameda Leandro Ribeiro, sn, Aldeia, 68600-000, Bragança, Pará, Brazil. Ph: 5591 34251209. Fax: 559134251593.
} 


\section{Introduction}

The sandy beaches of the Brazilian Amazon coast have considerable potential for the tourism industry, with their natural and well-preserved environments distributed along a coastline of 3,900 km. Approximately 650 sandy beaches are found on the coasts of the Brazilian states of Pará and Maranhão (Pereira et al., 2016a, 2016b). The development of recreational and tourism activities on these beaches is limited primarily to the prolonged rainy season, which lasts approximately six months. Access to many rural and semiurban beaches is also restricted, especially in the areas dominated by the large tract of mangrove, one of the most extensive in the world (Kjerfve and Lacerda, 1993), and most sites have low-quality infrastructure and services, often lacking such basic amenities as a public water supply or sewage disposal system. These limitations, in addition to the turbidity of the local waters caused by the region's extensive fluvial discharge (Geyer et al., 1996), tend to restrict the development of the local tourism industry (Pereira et al., 2014; Silva et al., 2013; Sousa et al., 2016).

Located on or near the equator, the sandy beaches found in the vicinity of the Amazon estuary are exposed to a complex landscape dominated by a diversity of rivers, islands, and tidal creeks exposed to meso-macro-hyper tides and moderate wind-wave energy, with tide-dominated characteristics. To the east and south of the estuary, the heavily indented macro-tidal coast is composed of dozens of estuaries, separated by low, mangrove-dominated peninsulas surrounded by dynamic barrier islands with tide-dominated or tidemodified beaches (Pereira et al., 2016a). At around $2.5^{\circ} \mathrm{S}$, in Maranhão, the 
coast is less indented, with less pronounced tides, and wave-dominated beaches (Pereira et al., 2016b).

The Amazon coast is characterized by a heterogeneous landscape, ranging from zones of intense urban development to sparsely-populated areas with little or no infrastructure or public services (Szlafsztein, 2012). The most popular beaches are subject to unplanned development, which has created a range of natural and anthropogenic hazards, related primarily to the erosion provoked by inadequate constructions, bacteriological contamination from sewage outfalls, litter pollution, and oil spills (Andrade et al., 2010; Pereira et al., 2014; Sousa et al., 2017). As these processes can affect the development of the tourism industry, effective regulation and planning is urgently required for the whole Amazon coast, in order to guarantee the establishment of a secure and sustainable tourist industry, with a minimum of hazards and risks for beach users. In this context, the principal objective of the present study was to describe the natural and social characteristics of sandy Amazon beaches, evaluating their recreational potential and the challenges for the development of the recreational use of those beaches.

The following description outlines the environmental and social features

of these sandy beaches that determine their potential for recreational and leisure activities, and the challenges for the development of the local tourism industry. Finally, a number of recommendations are presented for the improvement of the recreational use of coastal Amazon beaches.

\section{Geomorphological and physical features}

The Brazilian Amazon coast (Figure 1) encompasses approximately 35\% 
of the whole Brazilian coastline, without taking its numerous islands and indentations into account, and includes parts of the states of Amapá, Pará and Maranhão. The most popular sandy beaches are located on the coasts of the latter two states, given the large amounts of muddy sediments deposited on the Amapá coast by the Amazon River (Anthony et al., 2010). The sandy beaches in Pará and Maranhão are influenced by both estuarine and oceanic waters, which create ecologically rich and diverse environments (Nittrouer and DeMaster, 1996).

$<$ Insert Figure 1>

The sandy beaches of Pará reach $350 \mathrm{~km}$ inland from the mouth of the Amazon River $\left(0^{\circ}\right)$, and extend $650 \mathrm{~km}$ eastward to Gurupi Bay $\left(1^{\circ} \mathrm{S}\right)$. The western half of this zone is centered on the lower Amazon River and its numerous tributaries, islands and bays, including the world's largest fluvialmarine island, Marajó Island, and its elongated bay, Marajó Bay, whereas the eastern sector is the highly indented coast between Marajó and Gurupi bays (Figure 1), which is part of the Amazon Macrotidal Mangrove Coast, or AMMC (Souza-Filho, 2005). Pará has a coastline of approximately 2700 km, with more than 450 tide-dominated estuarine and oceanic sandy beaches (Pereira et al., 2016a).

In western Marajó Bay, that is, Marajó Island (Figure 2A), the shoreline is dominated by mangroves and interrupted by small rivers and creeks (Figure 2B). Most of the local recreational beaches are composed of fine to very fine sand, and the beach profile is typically fronted by ridged sand flats, hundreds of 
meters wide, with recurved spits (Figure 2B-C). Other areas are gently sloping and less broad, with the Barreiras Formation establishing coastal bluffs in many places. The presence of intertidal rocks also is a characteristic of this sector (Figure 2D). Muddy sediments can be found in part of the intertidal zone, mainly within the tidal channels. The most popular local beaches are in the towns of Soure (e.g., Pesqueiro, Figure 2B) and Salvaterra, e.g., Joanes (Figure 2E). This sector is between the Pará River and the Atlantic Ocean, and is dominated by fluvial waters during the rainy season and estuarine waters (with salinity normally below $10 \mathrm{PSU}$ ) during the dry season. Spring tides can reach $3 \mathrm{~m}$ and tidal currents run at up to 2 m.s.-1 (Costa et al., 2013).

$<$ Insert Figure 2>

Estuarine beaches can be also found on the eastern margin of Marajó Bay (Figure 3A), where the coast is dominated by mangroves, interspersed with large rivers and creeks, which dissect the coast into large bays, islands, and extensive tidal shoals (Figures 3B, E). Longshore sand bars with southward migration may be found in many places (Figure 3D).

The local beaches are also embayed between low headlands, where the low-lying coastal plateau of the Barreiras Formation reaches the shore. Intertidal rocks are found in this sector (Figure 3E). These estuarine beaches are typically narrow $(<200 \mathrm{~m})$ and composed of fine to very fine sand. Muddy sediments may be found in the intertidal zone, limiting the recreational use of the beach during low tide (Sousa et al., 2017). The most popular beaches are located on Mosqueiro, Outeiro, Cotijuba, and Colares islands, and in Barcarena 
and Icoraci. The tidal range is approximately $3 \mathrm{~m}$ during spring tides (DHN, 2017), and wave heights $\left(H_{\mathrm{s}}\right)$ of more than $1.5 \mathrm{~m}$ may occur on some beaches, e.g., Marahú (Figure 3C).

$<$ Insert Figure 3>

The highly indented shoreline between Marajó Bay and the Gurupi River (Figure 4A) consists of approximately 15 major bays associated with rivers and tidal creeks (Pereira et al., 2016a). These bays are separated by the drowned plateau which slopes seaward into low regressive barriers and mangroves, terminating in highly dynamic recurved tide-modified barrier islands.

The bays are filled with sandy tidal shoals and channels, and the beaches facing into the waves of the Atlantic Ocean are fronted by extensive tidal shoals formed mainly by fine and very fine sand, which extend for up to 2 km offshore (Souza Filho et al., 2006; Trindade et al., 2016). Extensive dune fields (Figures 4B-C), low-tide deltas (Figure 4D), and extensive ridged sand flats with recurved spits (Figure 4E) are present at some locations (Souza-Filho and Paradella, 2002, 2003). Due to the influence of the local macrotides (4-6 m) and moderate waves $\left(H_{\mathrm{s}}\right.$ up to $\left.2 \mathrm{~m}\right)$, the condition of the beaches varies considerably, with tide-modified beaches $(3<R T R<15)$ being found on the more exposed sections, and tide-dominated beaches $(R T R>15)$ on the more sheltered sections (Pereira et al. 2016a). The most popular beaches are Atalaia, Ajuruteua, and Princesa. During low spring tides, these sandy beaches are normally between 200 and 400 m wide, with a low intertidal gradient, of $\sim 1^{\circ}$ (Pereira et al., 2014). 
$<$ Insert Figure 4>

The $1240 \mathrm{~km}$ coastline of Maranhão (Figure 5A), the second longest in Brazil, is located between the Gurupi River $\left(1^{\circ} \mathrm{S}\right)$ and the Parnaíba Delta $\left(2.5^{\circ} \mathrm{S}\right)$. This littoral is divided into three sectors, which contain more than 200 beaches (Pereira et al., 2016b). The western coast extends for $520 \mathrm{~km}$ from the state border at the Gurupi estuary $\left(1^{\circ}\right)$ to the Gulf of Maranhão $\left(2.1^{\circ}\right)$, and contains 42 sandy beaches. This coast is also part of the AMMC, and is composed of some 20 funnel-shaped, tide-dominated estuaries, separated by low mangrove-dominated peninsulas fronted by barrier islands and tidemodified or tide-dominated beaches (Pereira et al., 2016b). The entire coast presents evidence of barrier regression in the form of inner beaches and foredunes terminating as spits extending into the estuaries, as observed at Alcântara (Figure 5B).

The central sector is occupied by the four channels of the funnelshaped tide-dominated Gulf of Maranhão, which has an outer shoreline of 490 km, which includes Cumã, São Marcos and Arraial bays. In this area, the tidal range may reach $7 \mathrm{~m}$ during during spring tides, and tidal currents may run at

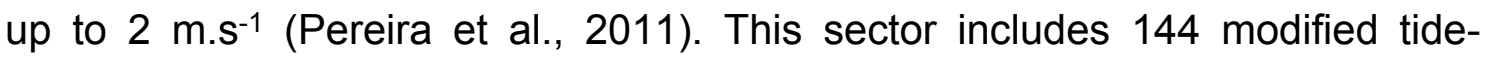
dominated beaches, located primarily along the outer $50 \mathrm{~km}$ of the estuarine shore, facing into the estuaries (Pereira et al., 2016b). These beaches can be classified as barrier systems backed by mangrove, and systems backed by bluffs carved from the Barreiras Formation, as observed at Olho d'Água beach in São Luís (Figure 5C). 
The eastern coast extends east for $230 \mathrm{~km}$ from the Gulf of Maranhão to the state border at the Parnaíba Delta. This relatively straight coastline has 26 exposed wave-dominated beaches backed by extensive transgressive dune fields formed during the Holocene and Pleistocene (Figure 5D). These beaches include Caburé and Atins, as well as Barra do Tatu, Moitas, Morro do Boi, Ponta do Mangue and Vassouras. In this sector, wave heights $\left(H_{\mathrm{s}}\right)$ can reach 3 $\mathrm{m}$ height, while tides decrease from 7 to $3 \mathrm{~m}$ toward the Parnaíba Delta (Figure $5 \mathrm{E})$.

$<$ Insert Figure 5>

\section{Alluring environments and tourist attractions}

The principal attraction of the region's rural and semi-urban beaches are their well-preserved, natural landscapes. Untouched, paradisiacal beaches can be found anywhere between the world's largest fluvial-marine island (Marajó) and the Parnaíba Delta. Other local attractions include arts and crafts, gastronomy, and cultural events such as folklore dances.

Some of the rural beaches are located in the vicinity of protected areas. These reserves include many Extractive Marine Reserves (EMRs), such as the Soure EMR, Mãe Grande EMR in Curuça, Maracaña EMR, São João da Ponta EMR, Tracuateua EMR, Caeté-Taperaçu EMR, Araí-Peroba EMR, and GurupiPiriá EMR, all located in Pará, and the Cururupu and Delta do Parnaíba EMRs, in Maranhão. Other types of protected area include the Environmental Protection Areas (EPAs) of Algodoal-Maiandeua, Urumajó, and Canelas Island, in Pará, and the Lençóis Maranhenses National Park in Maranhão. 


\section{Limitations on the tourism industry}

A number of natural features of the region, derived in particular from its climate and the high turbidity of its waters, limit the potential for the development of the local tourism industry. The relative isolation of the majority of Amazon beaches is also a major limitation.

The local climate is humid equatorial, with well-defined dry and rainy seasons. The recreational use of beaches in Pará and Maranhão is intense during the month of July (school vacation) and holiday periods, primarily during the second half of the year, which coincides with the dry season. The fluctuations in the Intertropical Convergence Zone (ITCZ) are the principal factor responsible for local rainfall patterns (Marengo, 1995). During the dry season, the ITCZ shifts to the Northern Hemisphere $\left(>2^{\circ} \mathrm{N}\right.$ latitude), resulting in lower rainfall rates (normally below $100 \mathrm{~mm}$ per month) on the coasts of Pará and Maranhão.

The high turbidity of the region's coastal waters is a negative feature for visitors to Amazon beaches. This turbidity is determined primarily by the region's enormous fluvial discharge, which results in high levels of suspended material (Geyer et al., 1996). Turbidity tends to be lower than 200 NTU when winds are relatively weak, typically during July (vacation period, Figure 6), or when fluvial discharge is lowest, at the end of the dry season, in November and December (Pereira et al., 2013; Silva et al., 2013; Sousa et al., 2016). During July month, water salinity varies between 2 and 18 PSU in estuarine beaches (Figure 6).

The majority of Amazon sandy beaches are relatively isolated due to the extensive areas of mangrove forest, and other natural features such as rivers, 
creeks and estuaries or, in the case of eastern Maranhão, extensive dune fields (Figures 4 and 5). Many beaches can only be reached by boat or, in some cases, airplane.

In addition to these natural features, the local tourism industry is also limited by a lack of infrastructure and public services (see above). In recent decades, while the local authorities have invested in improvements to the highway network, making many areas more accessible, little has been done to upgrade local infrastructure or services. At many beaches, while the number of private establishments - bars, restaurants, hotels, and guesthouses - has increased rapidly in recent years, public services (such as sanitation) have not been improved, and are generally insufficient to cope with the increase in demand, in particular during vacation periods.

$<$ Insert Figure 6>

\section{Beach development and beach user profiles}

Rural beaches have only rudimentary services and infrastructure. As some of these beaches are located within conservation units, specific legislation prohibits the construction of new buildings and even the access of motor vehicles. These beaches include Pesqueiro beach in the Soure EMR on Marajó Island (Figure 7A), Princesa beach in the Algodoal-Maiandeua EPA on Algodoal Island, and Caburé beach, in the Lençóis Maranhenses National Park. These beaches attract younger visitors interested in enjoying the local natural scenery. The isolation of some localities, which may require transportation by off-road vehicles, boats or even airplanes, often increases the costs of tourism 
significantly (Sousa et al., 2013).

As semi-urban beaches, e.g., Murubira (Mosqueiro Island), Atalaia (Salinópolis), and Olho d'Água (São Luís), offer more facilities than rural beaches, they tend to attract visitors more interested in the quality of the infrastructure than the natural features of the beach (Silva et al., 2013; Sousa et al., 2016).

At both rural and semi-urban beaches, the waterfront infrastructure includes bars and restaurants, private houses, and guest houses and hotels. In general, there are few streetlights, shops, and there is no public water supply or sanitation system (Figure 7B), and only intermittent garbage collection and street cleaning. Public toilets and showers, and car parking facilities are found only at a few beaches. At many beaches, in particular in rural areas, buildings are often precarious wooden structures built on inadequate sites, such as mangroves, restinga, dunes, and the intertidal zone (Figure 7B-C). More solid buildings, including mansions, can be found at many semi-urban or urban beaches (e.g., Farol-PA and Ponta de Areia-MA), located on intertidal and dune zones, cliffs or a few meters from the backshore or foreshore zones (Figure 7DE). The most urbanized coastal beaches are located in São Luís. These beaches offer good logistics and a diversity of privately-owned facilities, which provide beachgoers with amenities and leisure options, including hotels, restaurants, bars, and residential and commercial buildings (Silva et al., 2011a). However, the lack of an adequate public sanitation system (Figure 7F) has led to the prohibition of bathing on the beaches of São Luís (Silva et al., 2013).

$<$ Insert Figure 7> 


\section{Recreational Use}

The recreational use of Amazon beaches depends primarily on tidal conditions (high/low, spring/neap). Promenade and backshore areas are characterized by the presence of bars and restaurants, and during vacation periods, musical attractions are often available.

During the high spring tides, the intertidal zone, which normally accommodates practically all of a beach's visitors, disappears. The recreational use of the intertidal zone begins during the ebb tide, when the area is used for activities such as sports (football and volleyball), sunbathing, and the consumption of food and beverages at the tables provided by the owners of local bars and guesthouses. At many beaches, such as Atalaia, Olho d'Água, and Araçagi (Maranhão), cars are driven onto the beach and parked in this zone (Figure 7G). At many estuarine beaches, part of the intertidal zone is covered with mud, as observed at Colares and Pesqueiro, and during low tides, beachgoers tend to avoid bathing in these areas.

The surf zone, located at the water's edge, is used by bathers and enthusiasts of other aquatic leisure activities, such as surfing (including the estuarine beaches), jet skiing, kite surfing, and motor boating. In São Luís, however, the surf zone is rarely used for bathing because of the prohibitions enforced due to the contamination of the water, as discussed above (Silva et al., 2011a; 2013).

\section{Safety}

Natural (e.g., high hydrodynamics and fluvial discharge, the presence of rocks, intertidal channels, and dangerous animals) and anthropogenic (e.g., 
lack of services and infrastructure, unregulated land use) hazards result in a number of problems, such as erosion and contamination, and other risks for beachgoers. We outline below a number of the most important hazards that can affect beachgoers on Amazon beaches.

\subsection{Natural Hazards}

Physical hazards include strong tidal currents $\left(>1.5 \mathrm{~m} \mathrm{~s}^{-1}\right)$, rocks in the intertidal zone, cliffs, tides, which attain considerable heights (3-7 m, Figure 8), and moderate wave energy ( $H_{\max }$ up to $3 \mathrm{~m}$ during high tide, Figure 9 ). The stings of stingrays and the barbed fins of the catfish known locally as the "uricica" can provoke extremely painful injuries to bathers that step accidentally these fish. Jellyfish stings can also cause bathers extreme pain (Sousa et al., 2017).

In Marajó Bay, the strong tidal currents and the presence of cliffs and rocks in the intertidal zone are considered to be the principal physical hazards. On the less sheltered beaches, such as some of those on Mosqueiro Island, the moderate wave heights can be suitable for surfing, but dangerous for other beachgoers. Accidents involving animals, principally stingrays can be frequent on many beaches (Sousa et al., 2017).

Between Marajó Bay and the Gulf of Maranhão, the principal physical hazards are related to the strong tidal currents, moderate wave energy, macrotides (4-6 m), intertidal channels (Figure $7 \mathrm{H})$, the presence of rocks in the intertidal zone (Figure 7I), and animals such as the uricica catfish (Pereira et al., 2014; Brito et al., 2016). In the central and eastern sectors of the Maranhão coast, strong tidal currents, cliffs, tides of up to $7 \mathrm{~m}$ at São Luís, and waves 
increasing to $3 \mathrm{~m}$ in the Parnaiba Delta are considered the principal physical hazards for beachgoers (Pereira et al., 2016b). Jellyfish have caused some accidents, mainly involving children, in São Luís.

$<$ Insert Figure 8>

$<$ Insert Figure 9>

\subsection{Human Hazards}

Erosion has caused serious problems on most of the touristic beaches, where natural features and buildings or other infrastructure have been partially or completely destroyed by erosive processes. These processes occur mainly during the equinoctial spring tides, in March and September, and may result in the loss of dunes and mangroves, roads, power lines, and buildings (Alves and El-Robrini, 2006; Pereira et al., 2011, 2014). On rural beaches, intense erosion has led to the relocation of wooden structures further inshore, as observed on Ajuruteua and Vila dos Pescadores beaches (Pereira et al., 2009). In Ajuruteua rockwalls are been used to protect edifications and infrastructure. Precarious structures are found on some semi-urban beaches, and groins have been built in São Luís (Ponta de Areia beach).

Solid waste and sewage are the principal sources of contamination on the most popular Amazon beaches. Firstly, the lack of refuse collection or public sanitation, associated with the general lack of environmental consciousness of beachgoers, has negative results, such as unpleasant sights and odors, particularly during the vacation period and some bank holidays. The solid waste 
found typically on the beach and in the water include plastics (bags, bottles, cups, plates), drink cans, leftover food, paper, and human and animal excrement. Depending on the tidal range and refuse collection services, solid waste deposited on a beach may remain in place or be transported by local currents to adjacent coastal environments, such as mangroves. The accumulation of waste can also lead to infestation by flies and other insects (direct observation).

The inaccessibility of many island beaches, in particular those reachable only by boat, may also hamper the removal of waste. On Princesa beach, for example, part of the solid waste is deposited in the local dunes (Pinto et al., 2011).

Polluted water from local rivers also contributes to an increase in the contamination of coastal Amazon beaches. In fact, the lack of a public sanitation system throughout practically the whole Amazon coast, and the construction of rudimentary cesspits (Figure 7B) at buildings located within the intertidal zone, on the backshore or in the dunes, has an extremely negative effect on the quality of the water of the most popular Amazon beaches. As rural and semi-urban beaches are visited primarily during vacation periods, pollution by sewage peaks when the number of beachgoers reaches maximum levels, in particular at high tide, when the water level reaches the cesspits, and the beginning of the ebb tide. On urban beaches, such as those of São Luís, the disposal of sewage directly onto the beach has resulted in a universal ban on bathing since 2009 (Silva et al. 2013). This prohibition has had a considerable impact on recreational activities in the area, and consequently, on its economy. 
The presence of sewage also results in contamination by pathogenic organisms, such as fecal coliforms.

Risk levels on Amazon beaches increase during vacation periods, when local lifeguards (personal communication) record an increase in the number of drownings and other injuries. On rural and semi-urban beaches, risk levels increase primarily in July, during the school vacation, when beachgoer numbers increase dramatically, even though hydrodynamic energy decreases, as well as during the Easter (March-April) and Brazilian Independence Day (September) holidays, when equinoctial tides occur and hydrodynamic energy is higher. While lifeguards are posted daily on the urban beaches of São Luís, bathing has been banned due to sewage contamination. Surfing, kite surfing, and jet skiing are practiced on the most popular beaches and can be dangerous for other beach users, due to the lack of appropriate zoning.

While safety equipment (life buoys, lifejackets and life rafts) can be found on the most popular beaches, emergency and first aid services are restricted mainly to the urban beaches. At many rural and semi-urban beaches, emergency services or hospitals are typically found at distances of dozens of kilometers, reinforcing the need for first aid equipment (Pereira et al., 2014; Brito et al., 2016).

Another manmade hazard on many Amazon beaches is the presence of motor vehicles. Cars, buses and even trucks are driven onto many beaches and serious problems have been recorded, including accidents and traffic jams. During vacation periods, in particular at the weekend, vehicles are often trapped by the rapid surge of the incoming tide, as observed frequently on Atalaia beach (Silva et al., 2011b). 
The natural and social characteristics of Amazon beaches, focusing the limitations (challenges), attractions (potential for recreation) and hazards are summarized in Figure 10.

$<$ Insert Figure 10>

\section{Coastal Management actions}

Certain climatic features (e.g., temperatures, high rainfall, and strong winds) limit recreational activities at different latitudes. In the equatorial zone, the prolonged rainy season is the principal climatic feature limiting recreational activities. On the Amazon coast, however, recreational activities tend to be concentrated during July and other holiday periods, and normally involve local beachgoers. This use pattern may be related primarily to the preference of local beachgoers for freshwater sites, such as rivers or streams, which are abundant and accessible. This is reinforced by the turbid water found on most coastal beaches, and the general lack of adequate infrastructure or services, which tends to deter visitors from other Brazilian regions or countries. These problems are exacerbated by a lack of effective coastal management, in terms of both planning and actions, associated with population growth, which has even increased in many Amazon coastal cities (IBGE, 2018). However, the local authorities have created protected areas in some areas to control and mitigate the innumerable human activities that affect this coastal zone.

Both Pará and Maranhão have been working on the development of their respective state coastal management plans, although effective management strategies need to be implemented urgently to guarantee 
improvements for the recreational use of some beaches, primarily given the need to minimize the issues described above.

As natural features (i.e., prolonged periods of rainfall, high turbidity, low salinity, high hydrodynamic energy) cannot be controlled by human measures, the recreational use of Amazon beaches should be improved through the adoption of the following measures:

a) Adequate planning of land use to avoid erosion processes and morphodynamic changes, environmental degradation (dunes, mangrove, cliffs), and the destruction of infrastructure.

b) Beach zoning, to minimize the risk of accidents. This will require:

- the prohibition of cars and aquatic vehicles from specific areas;

- the zoning of aquatic activities, with areas for bathing and other aquatic sports being delimited by flags, buoys and signs;

- Signs, maps and pamphlets should be provided to alert visitors to the presence of natural hazards (waves, currents, rocks, etc.).

(c) Investment in local infrastructure and services. This should include:

- the construction of sewage treatment systems and the immediate closure of all sewage outlets that discharge effluents directly onto the beach;

- the monitoring of water quality to avoid bacteriological contamination, accidents and illness;

- the installation of an efficient system of waste collection, which should include an increase in the number of bins and disposal points on all beaches.

The specific characteristics of Amazon region, its social-economic and environmental trends, and the fragile nature of its infrastructure and services, in 
both the public and private sectors, should be used as guidelines for the development of an integrated coastal management plan for the entire Amazon coast, taking the development level of each beach into account.

\section{Conclusions}

The sandy beaches of the Amazon coast are located just south of the equator, adjacent to the mouth of the Amazon River, and set within a complex coastline of estuaries, inlets, and bays exposed to meso-macrotides and moderate wave energy. These well-preserved environments and their natural landscapes are their principal attractions for beachgoers, although the prolonged rainy season, the highly waters, and the lack of development of these beaches are all factors limiting their use. While the natural features of these beaches are the result of the climatic and hydrographic conditions, the lack development is a consequence of the minimal investment in infrastructure and public services by the local authorities. These services are insufficient, in general, and in particular during vacation periods. The natural features of these beaches, associated with the unplanned development, have resulted in widespread erosion and contamination, frequent accidents. During the equinoctial periods when hydrodynamic energy is at its highest, erosive processes have destroyed many buildings and some natural features, primarily in areas of unplanned development. The region's high hydrodynamic energy, associated with a lack of beach management plans, has led to an increase in the risk of accidents involving beachgoers, even on the beaches patrolled by lifeguards during vacation periods. Coastal planning and regulation is urgently required to ensure the development of a safe and sustainable tourism industry, 
and to reduce the hazards and risks for beachgoers. The strategies outlined in this paper may also be adapted to other coastal zones in other regions of the world that have similar natural and social characteristics.

\section{Acknowledgments}

The authors Sousa (141551/2012-7), Pereira (310909/2014-7 and 200629/2014-0) and Costa (309527/2014-7 and 200622/2014-5) would like to thank CNPq for research grants. We are also indebted to Stephen Ferrari for his careful correction of the English.

\section{References}

Alves, M.M.S., El-Robrini, M., 2006. Morphodynamics of a macrotidal beach: Ajuruteua, Bragança North Brazil. J. Coast. Res. SI 39, 949-951.

Andrade, M.M.N., Szlafstein, C.F., Souza-Filho, P.W.M., Araújo, A.R., Gomes, M.K.T., 2010. A socioeconomic and natural vulnerability index for oil spills in an Amazonian harbor: a case study using GIS and remote sensing. J. Environ. Manage. 91, 1972-1980.

Anthony, J.E., Gardel, A., Gratiot, N., Proisy, C., Allison, M.A., 2010. The Amazon-influenced muddy coast of South America: a review of mud-bankshoreline interactions. Earth Sci. Rev. 103, 99-121.

Brito, W.C., Pereira, L.C.C., Short, A.D., 2016. Beach Hazard and Risk Perception of Lifeguards Working in a Macrotidal Amazon Beach. J. Coast. Res. SI 75, 1217-1221.

Costa, K.G., Bezerra, T.R., Monteiro, M.C., Vallinoto, M.N., Berredo, J.F., Pereira, L.C.C., Costa, R.M., 2013. Tidal-Induced Changes in the Zooplankton Community of an Amazon Estuary. J. Coast. Res. 289, 756-765.

DHN. Diretoria de Hidrografia e Navegação, 2017. Tábuas de maré para o fundeadouro de Salinópolis (Estado do Pará). http://www.dhn.mar.mil.br/chm/tabuas (accessed 08 April 2017).

Geyer, W.R., Beardsley, R.C., Lentz, S.J., Candela, J., Limeburner, R., Johns, 
W.E., Castro, B.M., Soares, I.D., 1996. Physical oceanography of the Amazon shelf. Cont. Shelf Res. 16, 575-616.

Instituto Brasileiro de Geografia e Estatística - IBGE, 2018. Brasília. http.://www.ibge.gov.br/cidadesat/ (accessed 05 May 2018).

Kjerfve, B., Lacerda, L.D., 1993. Mangroves of Brazil, in: Lacerda, L.D. (Ed.), Conservation and sustainable utilization of mangrove forests in Latin America and Africa regions. International Society for Mangrove Ecosystems, Okinawa, pp. 245-272.

Marengo, J., 1995. Interannual variability of deep convection in the tropical South American sector as deduced from ISCCP C2 data. Int. J. Climatol. 15, 995-1010.

Nittrouer, C.A., DeMaster, D.J., 1996. The Amazon shelf setting tropical, energetic, and influenced by a large river. Cont. Shelf Res. 16, 553-574.

Pereira, L.C.C., Oliveira, S.M.O., Costa, R.M., Costa, K.G., Vila-Concejo, A., 2013. What happens on an equatorial beach on the Amazon coast when La Niña occurs during the rainy season? Estuar. Coast. Shelf Sci. 135, 116-127.

Pereira, L.C.C., Ribeiro, C.M.M., Monteiro, M.C., Asp, N., 2009. Morphological and sedimentological changes in a macrotidal sand beach in the Amazon littoral (Vila dos Pescadores, Pará, Brazil). J. Coast. Res. SI 56 (1), 113-117.

Pereira, L.C.C., Silva, N.I.S., Costa, R.M., Asp, N.E., Costa, K.G., VilaConcejo A., 2012. Seasonal changes in oceanographic processes at an equatorial macrotidal beach in northern Brazil. Cont. Shelf Res. 43, 95-106.

Pereira, L.C.C., Trindade, W.N., Silva, I.R., Vila-Concejo, A., Short, A.S., 2016b. Maranhão Beach Systems, Including the Human Impact on São Luís Beaches, in: Short, A.D., Klein, A.H.F. (Eds.), Brazilian Beach Systems. $1^{\text {st }}$ edn. Springer, Suiça, pp. 125-152.

Pereira, L.C.C., Vila-Concejo, A., Costa, R.M., Short, A.D., 2014. Managing physical and anthropogenic hazards on macrotidal Amazon beaches. Ocean Coast. Manage. 96, 149-162.

Pereira, L.C.C., Vila-Concejo, A., Short, A.D., 2016a. Coastal morphodynamic processes on the macro-tidal beaches of Pará state under tidally-modulated wave conditions, in: Short, A.D., Klein, A.H.F. (Eds.), Brazilian Beach Systems. $1^{\text {st }}$ edn. Springer, Suíça, pp. 95-124.

Pereira, L.C.C., Vila-Concejo, A., Trindade, W.N., Short, A.D., 2011. Influence 
of high-energy conditions on beach changes in tide-dominated (Amazon, Brazil) and wave-dominated (NSW, Australia) coastal environments. J. Coast. Res. 64, 115-119.

Pinto, K.S.T., Pereira, L.C.C., Vila-Concejo, A., Gorayeb, A., Sousa, R.C., Costa, R.M., 2011. Effects of the lack of coastal planning on water quality and land use on a macrotidal beach (Atalaia, Pará) in the amazon region. J. Coast. Res. SI 64, 1401-1405.

Silva, I.R., Pereira, L.C.C., Sousa, R.C., Oliveira, S.M.O., Guimarães, D., Costa, R.M., 2011a. Amazon beaches (São Luís, Brazil): recreational use, environmental indicators, and the perception of beachgoers. J. Coast. Res. 64, 1287-1291.

Silva, I.R., Pereira, L.C.C., Trindade, W.N., Magalhães, A., Costa, R.M., 2013. Natural and anthropogenic processes on the recreational activities in urban Amazon beaches. Ocean Coast. Manage. 76, 75-84.

Silva, N.I.S., Pereira, L.C.C., Vila-Concejo A., Gorayeb, A., Sousa, R.C., Asp N.E., Costa R.M., 2011b. Natural and social conditions of Princesa, a macrotidal sandy beach on the Amazon Coast of Brazil. J. Coast. Res. SI 64, 1979-1983.

Sousa, R.C., Pereira, L.C.C., Costa, R.A.M., Jimenez, J.A., 2017. Management of estuarine beaches on the Amazon coast though the application of recreational carrying capacity indices. Tourism Manag. 59, 216225.

Sousa, R.C., Pereira, L.C.C., Costa, R.M., 2013. Water quality at touristic beaches on the Amazon coast. J. Coast. Res. SI 65, 1057-1062.

Sousa, R.C., Pereira, L.C.C., Jiménez, J.A., 2016. Estuarine beaches of the Amazon coast: environmental and recreational characterization. J. Coast. Res. SI 70 (1), 705-709.

Souza Filho, P.W.M., Martins, E.S.F., Costa, F.R., 2006. Using mangroves as a geological indicator of coastal changes in the Braganc-a macrotidal flat, Brazilian Amazon: A remote sensing data approach. Ocean Coast. Manage. 49, $462-475$

Souza Filho, P.W.M., Paradella, W.R., 2002. Recognition of the main geobotanical features along the Bragança mangrove coast (Brazilian Amazon Region) from Landsat TM and RADARSAT-1 data. Wetl. Ecol. Manag. 10, 123- 
132.

Souza Filho, P.W.M., Paradella, W.R., 2003. Use of synthetic aperture radar for recognition of Coastal Geomorphological Features, land-use assessment and shoreline changes in Bragança coast, Pará, Northern Brazil. An. Acad. Bras. Cienc. 75 (3), 341-356.

Souza-Filho, P.W.M., 2005. Costa de manguezais de macromaré da Amazônia: cenários morfológicos, mapeamento e quantificação de áreas usando dados de sensores remotos. Rev. Bras. Geofísica. 23(4), 427-435.

Szlafstein, C.F., 2012. Development projects for small rural communities in the Brazilian Amazon region as potential strategies and practices of climate change adaptation. Mitigation and Adaptation Strategies for Global Change 19, 143160.

Trindade, W. N.; Pereira, L. C. C.; Vila-Concejo, A., 2016. Tidal Modulation of Moderate Wave Energy on a Sandy Tidal Flat on the Macrotidal Amazon Littoral. Journal of Coastal Research, SI75, 487-491. 


\section{Figure Captions}

Figure 1. Brazilian Amazon Coast, showing the mouth of the Amazon Estuary, Marajó Island, Marajó Bay, the indented coast of eastern Pará and western Maranhão, and the eastern Maranhão coast, highlighting São Marcos Bay and Lençóis Maranhenses (Source: Google Earth).

Figure 2. Marajó Island and its main beaches (A), highlighting Pesqueiro, which is fronted ridged sand flats, hundreds of meters wide (B), the shoreline at Soure, with recurved spits (C), Salvaterra showing intertidal rocks indicated by a red line (D) and Joanes, with a high-tide beach (E) (Source: Google Earth).

Figure 3. Principal beaches on Mosqueiro Island, on the eastern margin of Marajó Bay (A), with details of Marahú beach (B) and waves breaking in a recreational sector (C), longshore sand bar with southward migration at Carananduba beach (D), and Farol beach, showing an embayment between low headlands (E) (Source: Google Earth).

Figure 4. The indented shoreline between Marajó and Gurupi bays (A), showing ridged sand flats adjacent to the dune fields at Princesa (B) and Atalaia (C) beaches, creeks and channels at both beaches and at Ajuruteua (D), and recurved spits at Vila dos Pescadores (E) (Source: Google Earth).

Figure 5. Coastline of Maranhão (A), showing the recurved spits at Alcântra (B), urban beaches in São Luís (C), the extensive dune fields in Lençóis Maranhenses (D) and the Parnaíba Delta (E) (Source: Google Earth).

Figure 6. Turbidity and salinity values recorded in vacation period within three bays influenced by different levels of fluvial discharge: low (Caeté Bay), intermediate (São Marcos Bay), and high (Marajó Bay). Col Colares, Mur 
Murubira, Pesq Pesqueiro, SM São Marcos, Cal Calhaus, OA Olho d'Água, VP Vila dos Pescadores, Aju Ajuruteua.

Figure 7. Pesqueiro beach on Marajó Island, in the Soure EMR (A), rudimentary cesspits (B), a rural beach on Marajó Island (C), buildings on an erosive area in Salinópolis (D), buildings on dunes at Ponta de Areia (E), presence of sewage at Olho d'Água $(F)$, cars driven onto Atalaia beach $(G)$, intertidal channels on Ajuruteua beach $(\mathrm{H})$, presence of rocks in the intertidal zone $(\mathrm{I})$.

Figure 8. Tidal ranges on estuarine and oceanic Amazon beaches. PB Porto de Belém, IM Ilha de Marajó, PT Porto de Tutóia, Mur Murubira, Col Colares, Gur Gurupi, Par Paracauari, IG Ilha dos Guarás, Mar Marudá, Pri Princesa, FS Fundeadouro de Salinas, Tap Taperaçu, Aju Ajuruteua, VP Vila dos Pescadores, TA Terminal Alumar, TPM Terminal Ponta da Madeira, PI Porto de Itaqui, SL São Luís. Data in red symbols are from DHN and in green colours from previous studies (Pereira et al. 2012, 2013, 2014; Silva et al. 2013; Sousa et al. 2017). Tidal ranges in Pará state are arranged inside the green circle and in Maranhão inside the orange circle.

Figure 9. The relationship between the $H_{\max }$ and $H_{\mathrm{s}}$ on some recreational Amazon beaches. Col Colares, SM São Marcos, Mur Murubira, Cal Calhaus, OD Olho d'Água, Mar Marudá, Pri Princesa, Pesq Pesqueiro, Ata Atalaia, Aju Ajuruteua.

Figure 10. Limitations, attractions, and natural and anthropogenic hazards found on rural, semi-urban and urban Amazon beaches. 


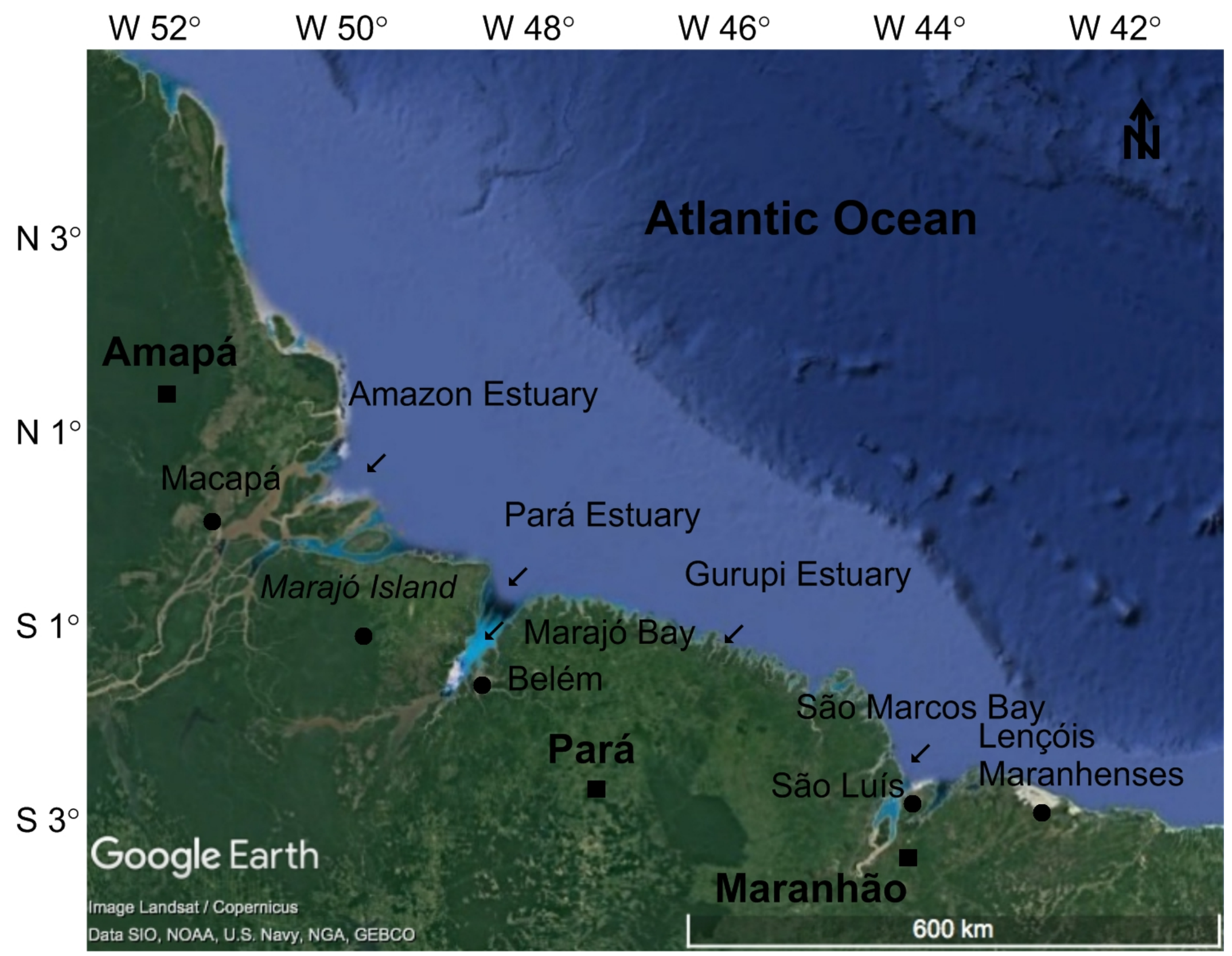


W 49 $18^{\prime} \mathrm{W} 49^{\circ} 06^{\prime} \mathrm{W} 48^{\circ} 54^{\prime} \mathrm{W} 48^{\circ} 42^{\prime} \mathrm{W} 48^{\circ} 30^{\prime} \mathrm{W} 48^{\circ} 18^{\prime} \mathrm{W} 48^{\circ} 06^{\prime} \mathrm{W} 47^{\circ} 54^{\prime}$

$\mathrm{S} 0^{\circ} 18^{\prime}$

Marajó /sland
Maresqueiro Beacho

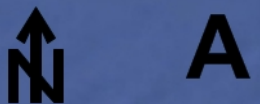

$\mathrm{S} 0^{\circ} 30^{\prime}$

S $0^{\circ} 42$ Salvaterran D

S $0^{\circ} 54$ Joanes Beach $\mathrm{E}$

$\mathrm{S} 1^{\circ} 06^{\prime}$

$S 1^{\circ} 18^{\prime}$

Google Earth

Image Landsat/ Copernicus

Data SIO, NOAA U.S. Nayy, NGA, GEBCO

Image $\odot 2018$ TerraMetrics
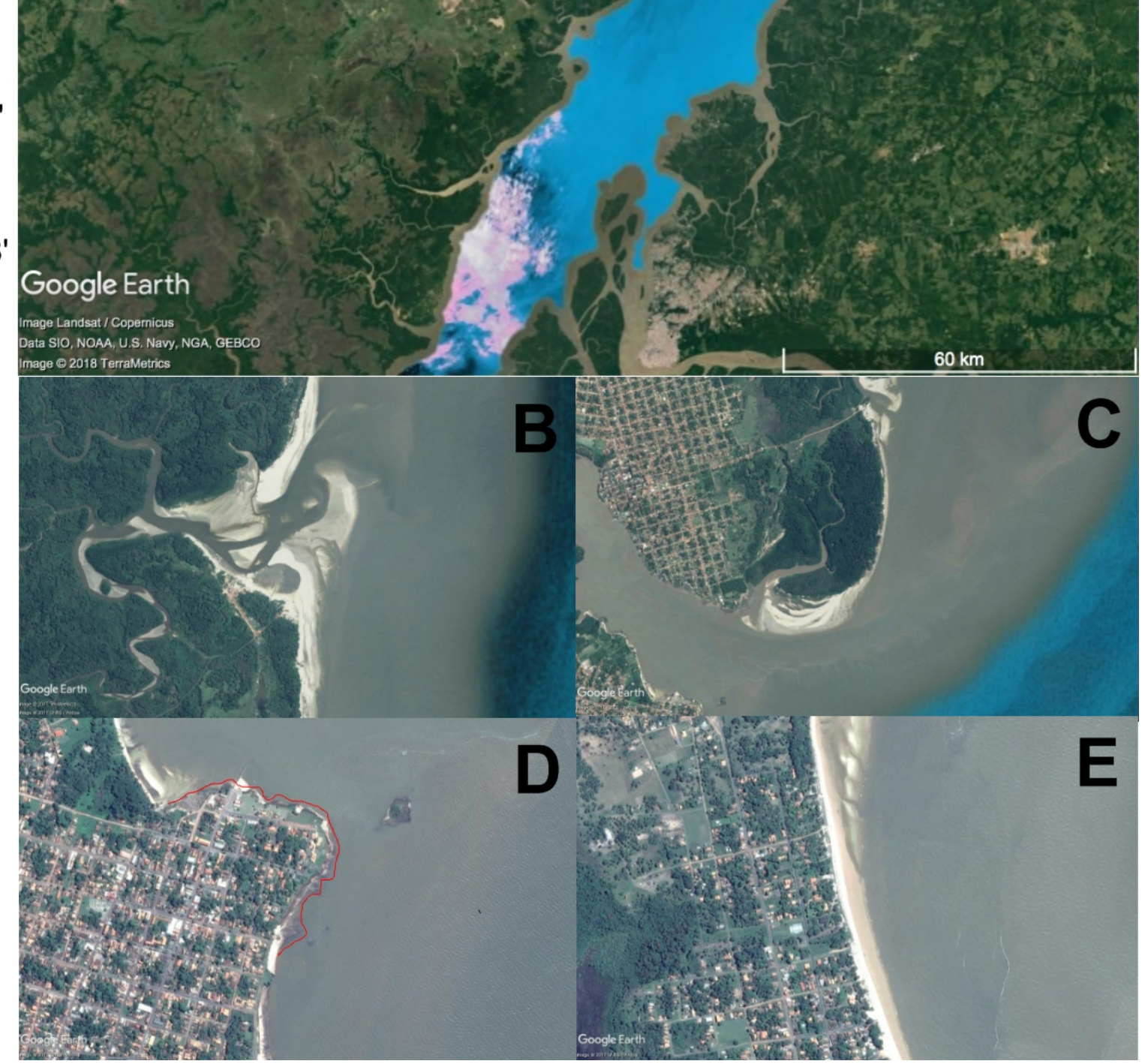

Marajó Bay 


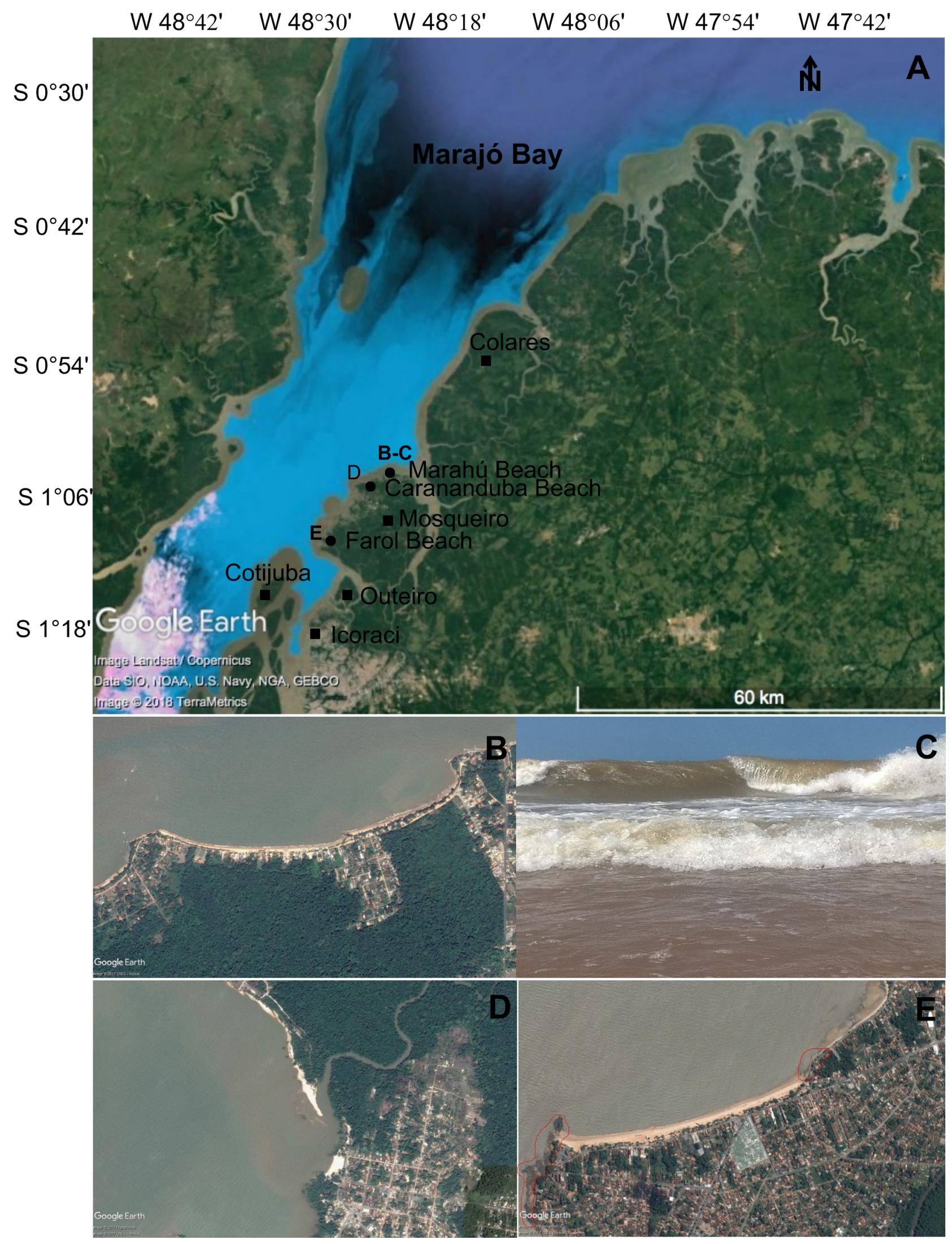



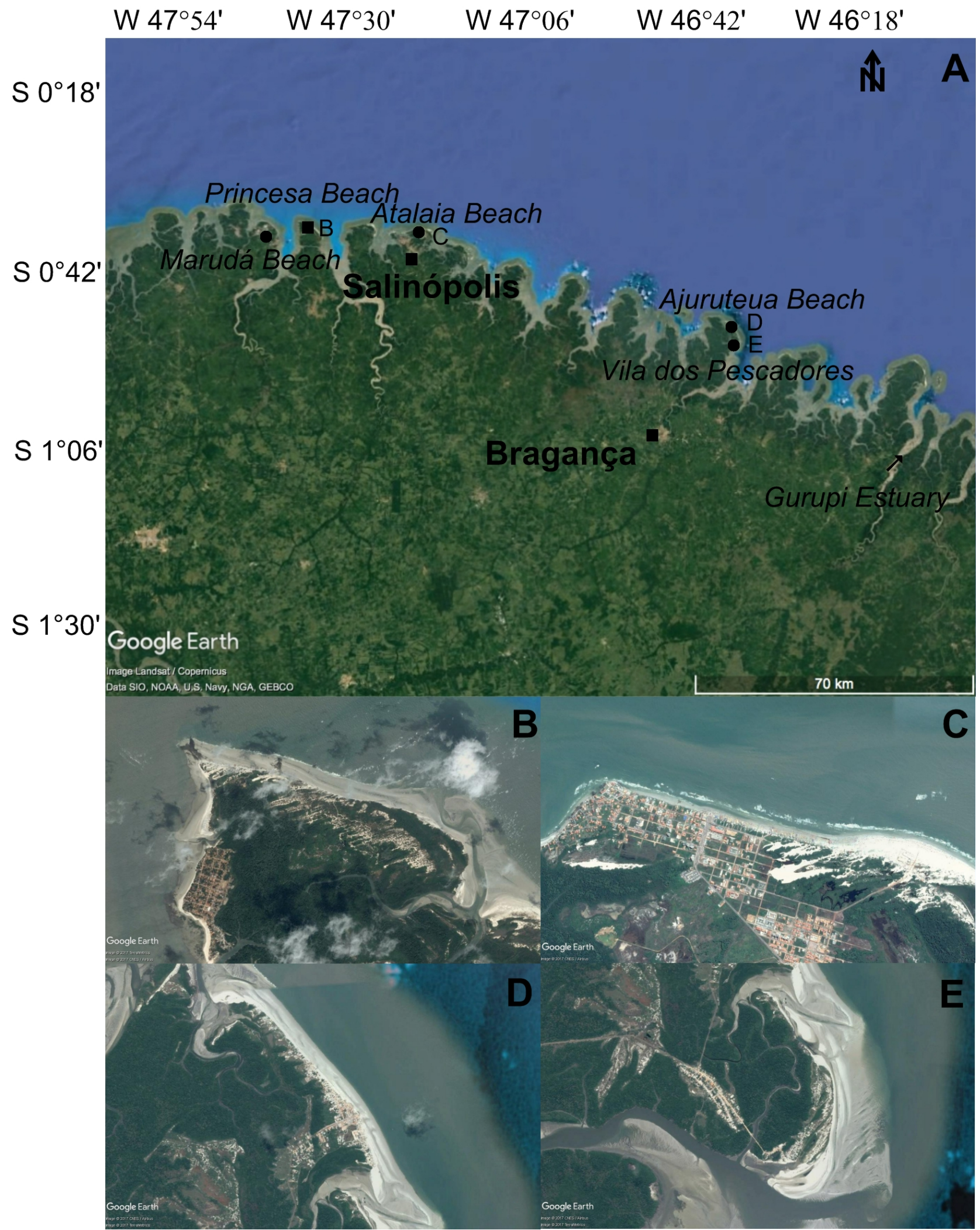


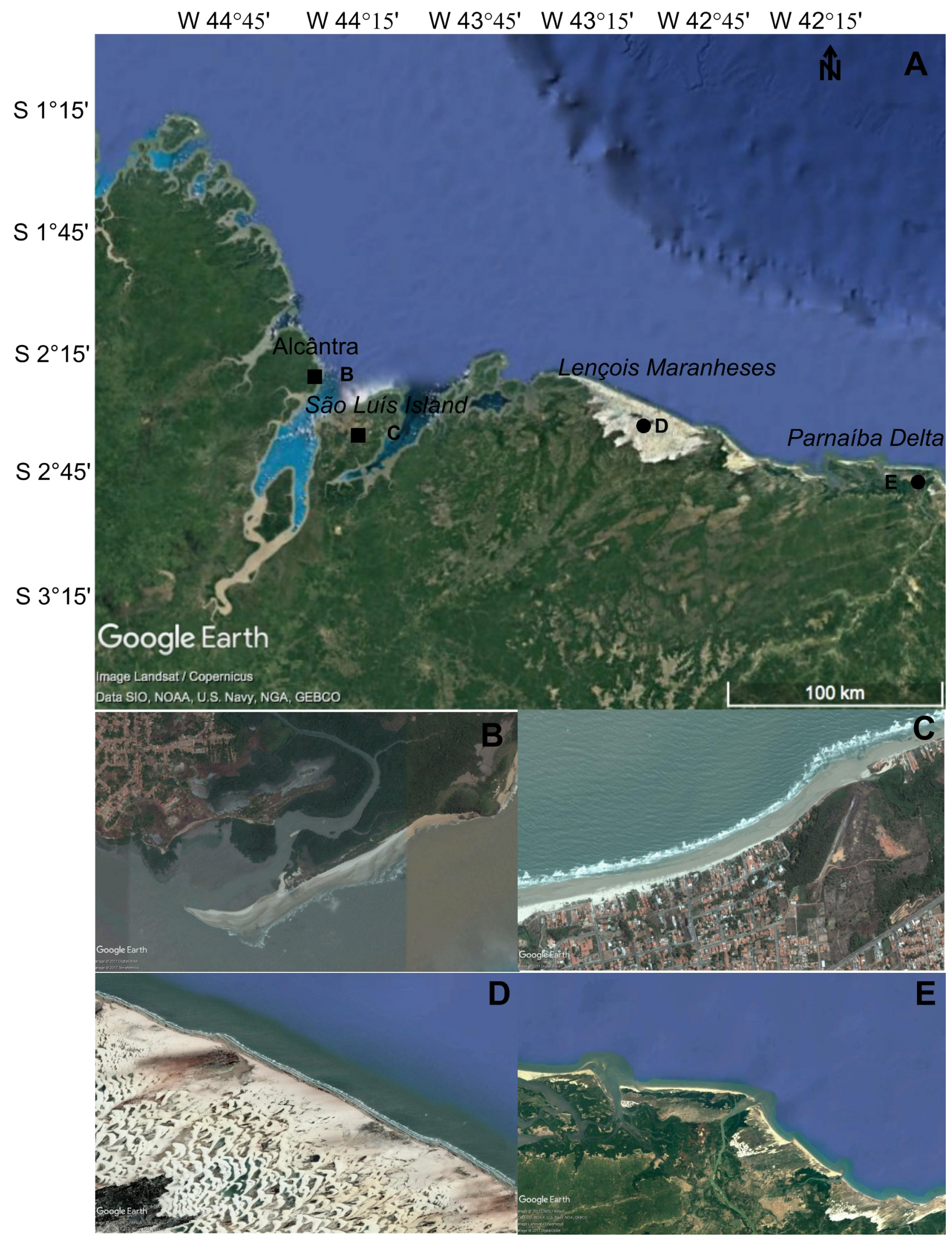




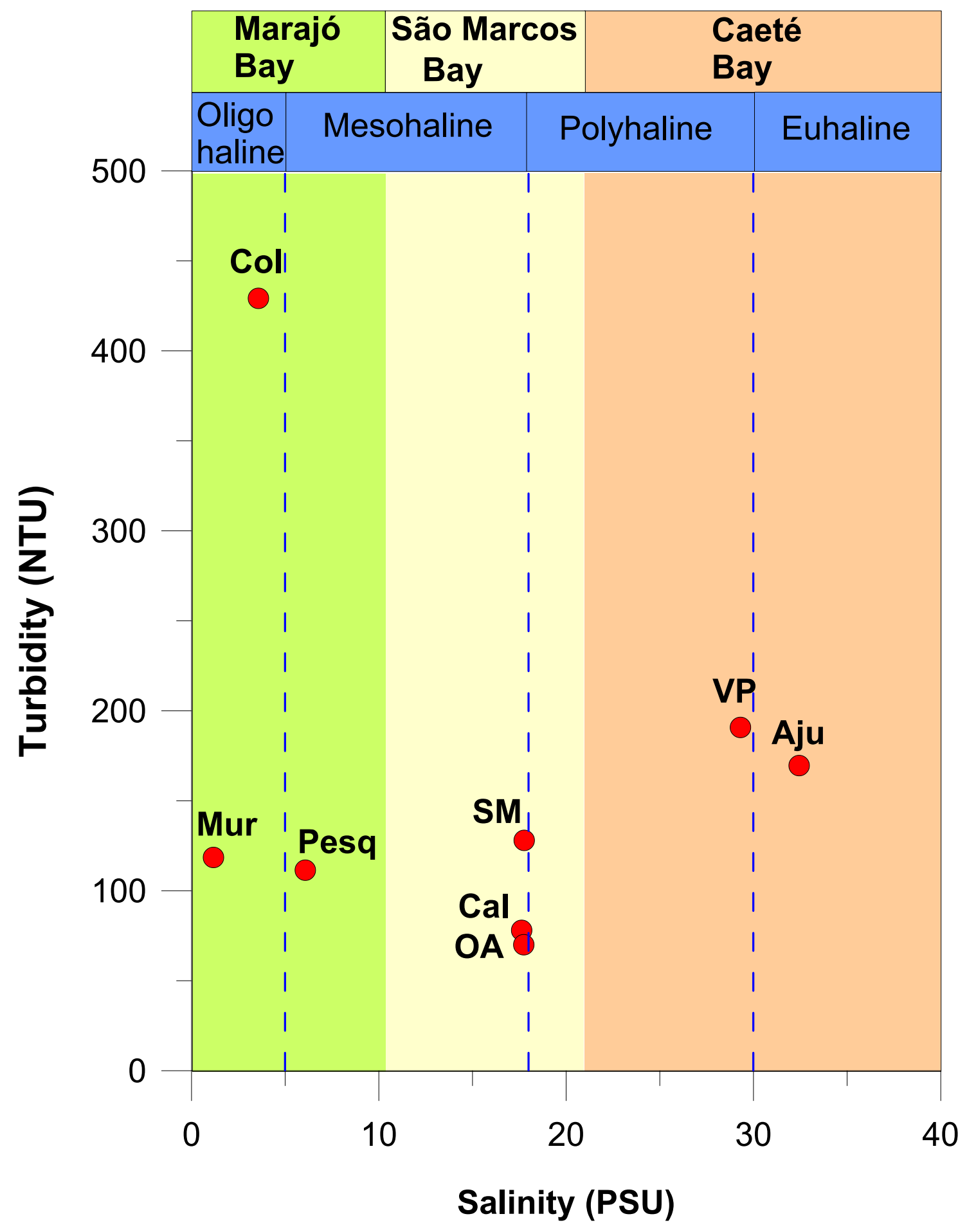




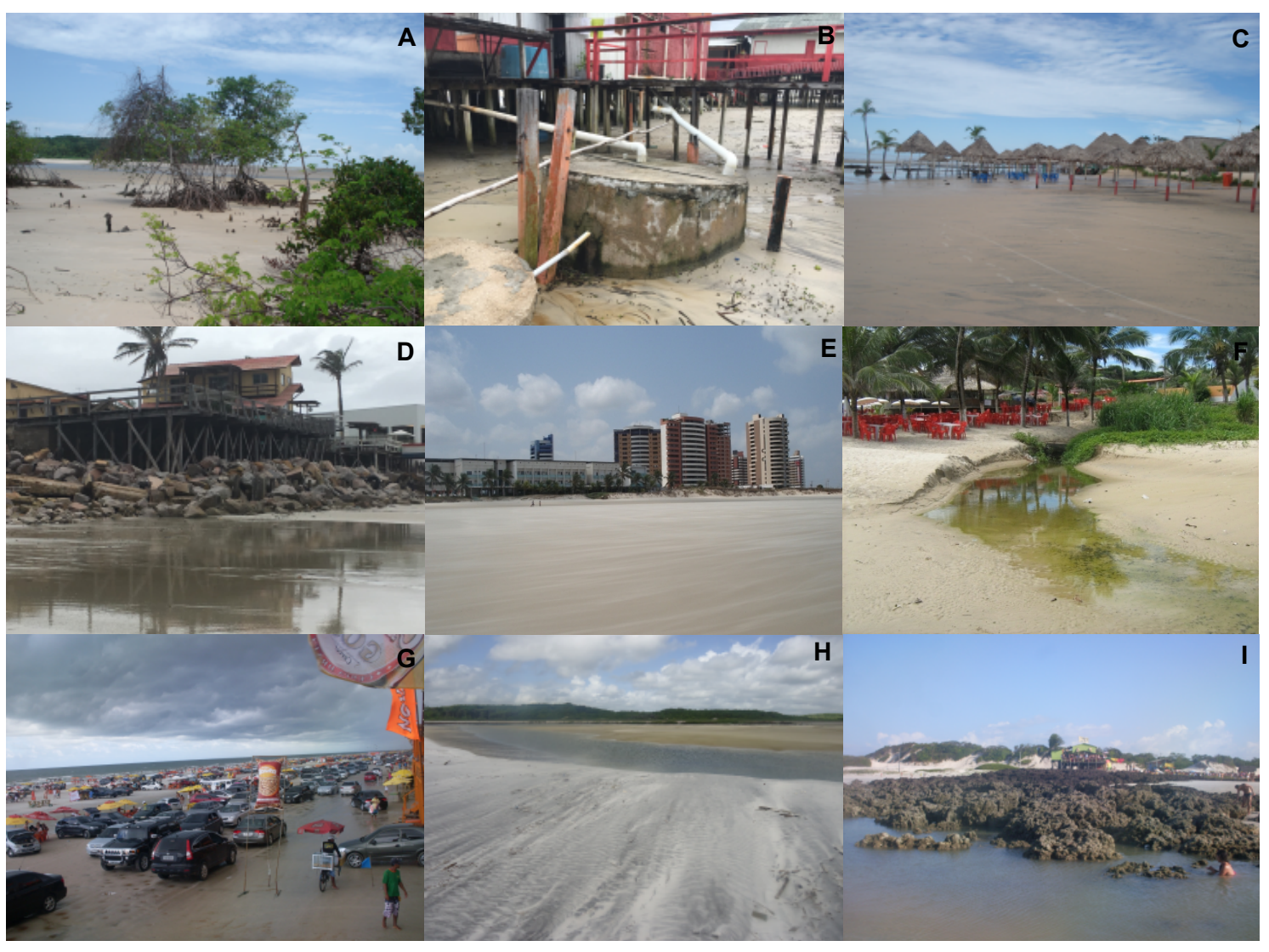

Figure 7. 


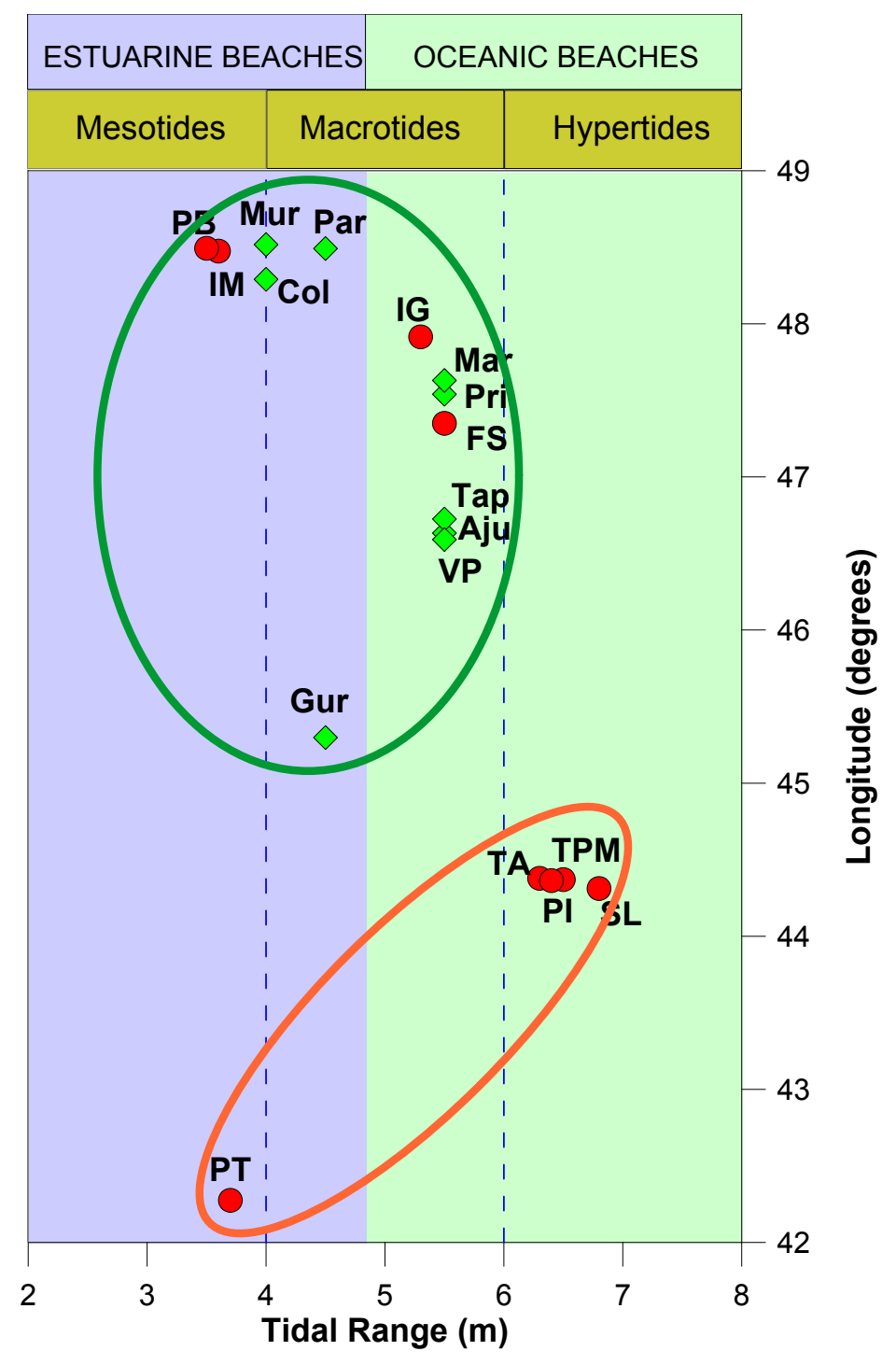

Figure 8. 


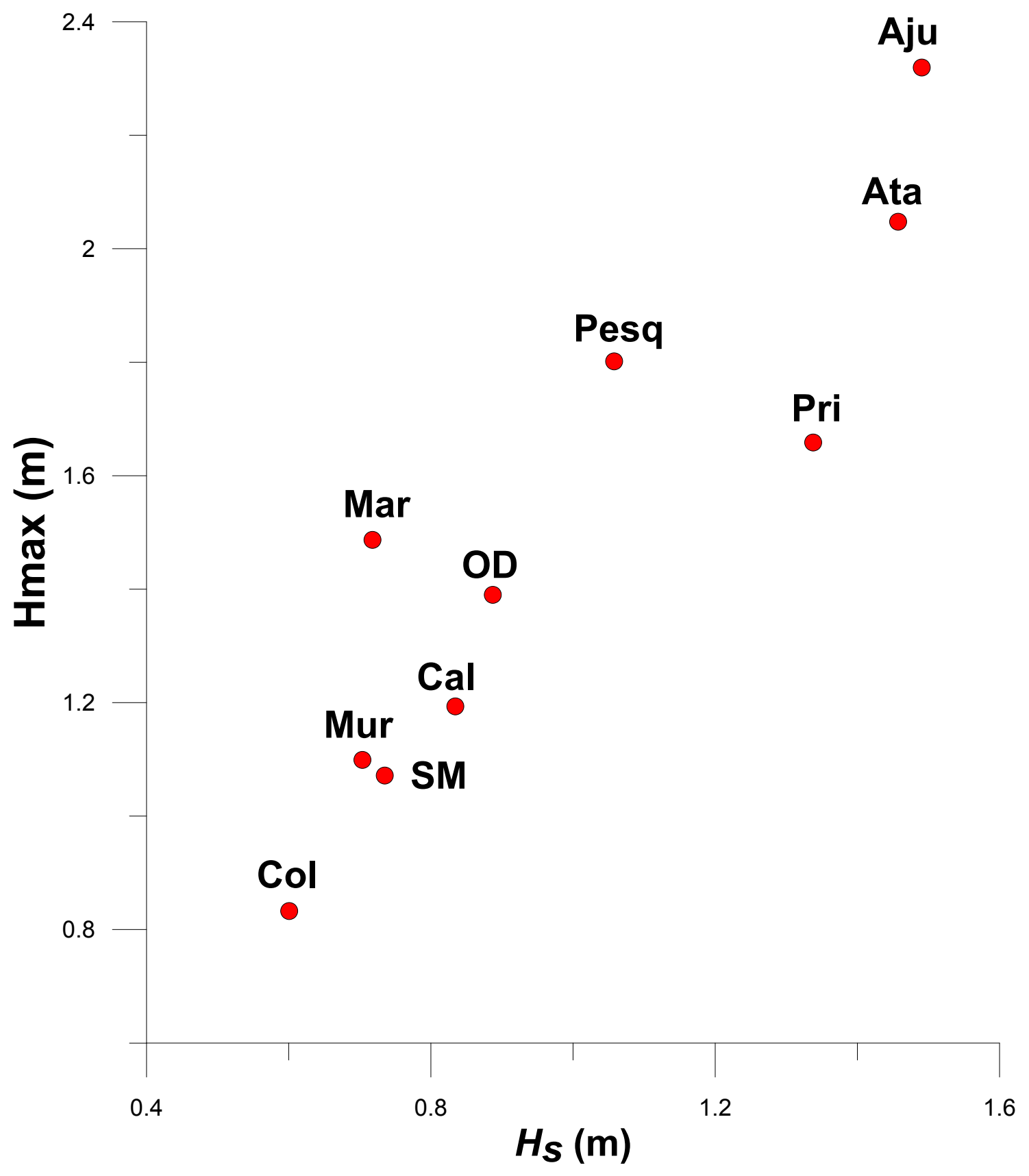

Figure 9. 


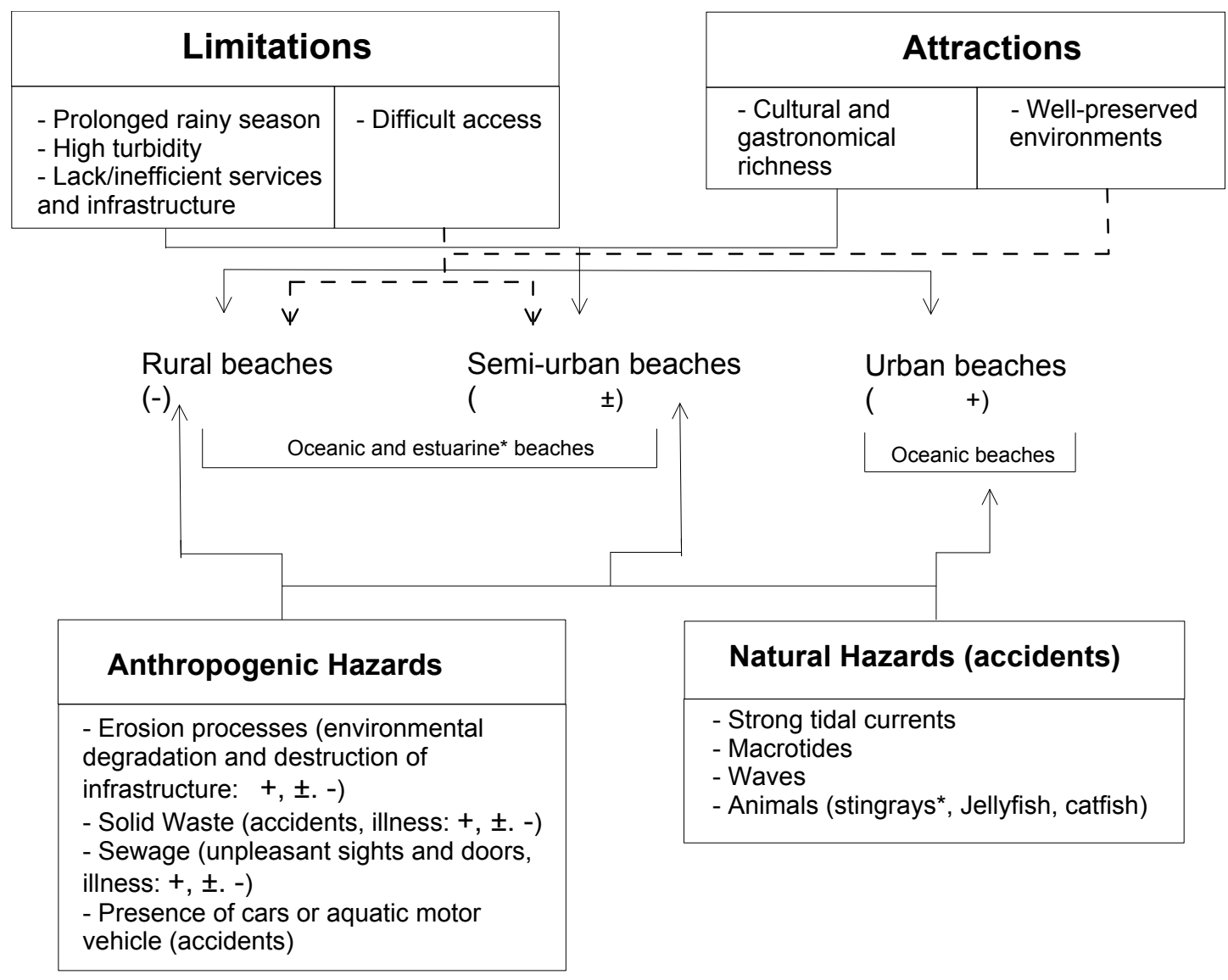

Figure 10. 